\title{
Can neurodegenerative disease be defined by four 'primary determinants': anatomy, cells, molecules, and morphology?
}

\author{
Richard A. Armstrong \\ Vision Sciences, Aston University, Birmingham, United Kingdom
}

\begin{abstract}
Traditional methods of describing and classifying neurodegenerative disease are based on the clinico-pathological concept supported by molecular pathological studies and defined by 'consensus criteria'. Disease heterogeneity, overlap between disorders, and the presence of multiple co-pathologies, however, have questioned the validity and status of many traditional disorders. If cases of neurodegenerative disease are not easily classifiable into distinct entities, but more continuously distributed, then a new descriptive framework may be required. This review proposes that there are four key neuropathological features of neurodegenerative disease (the 'primary determinants') that could be used to provide such a framework, viz., the anatomical pathways affected by the disease ('anatomy'), the cell populations affected ('cells'), the molecular pathology of 'signature' pathological lesions ('molecules'), and the morphological types of neurodegeneration ('morphology'). This review first discusses the limitations of existing classificatory systems and second provides evidence that the four primary determinants could be used as axes to define all cases of neurodegenerative disease. To illustrate the methodology, the primary determinants were applied to the study of a group of closely related tauopathy cases and to heterogeneity within frontotemporal lobar degeneration with TDP-43 proteinopathy (FTLD-TDP).
\end{abstract}

Key words: neurodegenerative disease, primary determinants, anatomy, cells, molecules, neurodegeneration.

\section{Introduction}

Traditional methods of describing and classifying cases of neurodegenerative disease are based on the original clinico-pathological concept, viz., a distinct clinical profile in combination with 'signature' pathological lesions. This system was used to describe the first cases of Alzheimer's disease (AD) [2], Pick's disease (PiD) [139], dementia with Lewy bodies (DLB) [107], and Creutzfeldt-Jakob disease (CJD) $[44,88]$. Subsequently, these original descrip- tions were refined and modified by molecular studies which resulted in the discovery of disease-specific antibodies and enabled the molecular signature of brain lesions to be established [20,59]. Ultimately, 'consensus criteria' have been established for the majority of disorders, e.g., AD $[120,125,133,162]$, DLB [120], multiple system atrophy (MSA) [71,72], and progressive supranuclear palsy (PSP) $[108,109]$, representing the coordinated views of experts in the field regarding the most important clinical and 
pathological features useful in diagnosis. As a result, neurodegenerative disorders have continued to be regarded as more or less distinct 'entities', neuropathologically defined by signature pathological lesions, and characterised by a specific molecular pathology [20,59].

Recent research, however, has revealed considerable heterogeneity within existing disorders [15,22], overlap between closely related entities $[19,55,63,76]$, and the co-occurrence in individual cases of two or more co-pathologies $[19,93,172]$. Hence, in a recent comparative study of 1032 cases representing ten different disorders, 361 cases, approximately 35\% of the sample, were excluded largely as a result of multiple pathology [25]. Not only do these exclusions ignore a large quantity of data, a bias is also created in favour of 'typical' or 'pure' examples of a disorder, thus ignoring potential intermediate, overlap, or multiple pathology cases. As a consequence, a reconsideration of existing disease entities and a new descriptive framework which can accommodate overlap and heterogeneity may be necessary $[8,19,54,62$, 128,137].

An alternative method of describing cases of neurodegenerative disease is to use a geometrical system based on 'ordination', i.e., by arranging individual cases with reference to a co-ordinate frame so that their similarities and differences can be spatially represented $[8,15,22,140]$. In such a system, there may be no attempt to name a disorder or to classify cases into any pre-existing groups, but only to plot individual cases with reference to the co-ordinate frame. Location of a case would reveal its similarities and differences to other cases, and proximity to similar cases may reveal underlying common pathological mechanisms. To define the axes of such a coordinate frame, however, would require quantitative measures of a range of neuropathological variables.

This review proposes that there are four key features of neurodegenerative disease (the 'primary determinants') which could be used to provide such a descriptive framework, viz., the anatomical pathways affected by the disease ('anatomy'), the cell populations affected ('cells'), the major molecular pathology of the 'signature' pathological lesions ('molecules'), and the morphological types of neurodegeneration ('morphology'). Hence, this review discusses: (1) limitations of existing classificatory systems, (2) evidence that the four primary determinants could provide a description of cases of neu- rodegenerative disease, (3) whether the four determinants are 'independent' variables, (4) whether the four determinants should be differentially weighted, and (5) describes the application of the method to the study of a group of closely-related tauopathy cases and heterogeneity within frontotemporal lobar degeneration with TDP-43 proteinopathy (FTLD-TDP) [22].

\section{Limitations of existing classifications}

Several studies have questioned whether neurodegenerative diseases are distinct or whether individual cases represent points in a 'continuum' of neuropathological change $[8,19,20]$. Hence, extensive overlap was observed between cases of $A D$ and Parkinson's disease (PD), interpreted as the action of common pathogenic mechanisms within vulnerable neuronal populations [137]. The authors argued that currently defined disease entities failed to deal with disease overlap and that a new classification should be considered [137]. In addition, Forstl [62] argued that the traditional clinico-pathological concept often accommodates genetically and clinically diverse conditions within the same group and therefore may have outlived its usefulness. The frequent use by authors of such terms as 'complex syndrome', 'spectrum of disorders', 'multiple pathologies', or even 'continuum' testifies to the extent to which boundaries between different disorders are more indistinct than previously thought $[8,38,68,160]$.

Central to the argument of how neurodegenerative disease should be classified has been the status of $A D[101,118]$. Alzheimer's disease is heterogeneous [145] and can be divided into clinically relevant subgroups such as sporadic $A D$ (SAD), tangle only $A D$, and the various genetic subtypes of familial AD (FAD), but only one subgroup actually corresponds to the disease originally described by Alzheimer [169]. In addition, a number of descriptive terms are used to describe $A D$ co-pathology, e.g., AD neuropathological change (ADNC), and neurofibrillary tangle (NFT)-only change in medial temporal lobe (NFT-MTL). Defining exact criteria for AD has always been difficult due to phenotypic heterogeneity, the absence of specific markers, and overlap of pathology with cognitively normal brain and related disorders $[7,90]$. Hence, the term 'AD' may describe disease subgroups with markedly different characteristics, and it has been suggested that the looser term 'Alzheimer syndrome' 
could be used or the term 'AD' dispensed with altogether [169]. If AD was to disappear as an entity, it would have significant implications for the status of many closely related disorders such as argyrophilic grain disease (AGD) $[32,163,178]$, vascular dementia (VD) $[95,106]$, and DLB [120].

The status of many other classically defined disorders has been equally controversial. Pick's disease [139], for example, is defined pathologically by the presence of tau-immunoreactive Pick bodies (PB) and abnormally enlarged neurons ('Pick cells'), but many cases of clinically typical PiD are at variance with these classic neuropathological features [98], e.g., some clinically typical PiD cases may lack PB [83]. Moreover, there is no convincing evidence linking the clinical symptoms of PiD with its histology, a challenge to the original clinico-pathological concept [60]. Subsequently, PiD became subsumed within the concept of 'frontotemporal dementia' (FTD) [87], but this classification also resulted in a heterogeneous group of disorders with considerable overlap between its constituent members [19]. Subsequent genetic and molecular studies have led to considerable changes in the classification and nomenclature within FTD and its neuropathological variants, viz. fronto-temporal lobar degeneration (FTLD) $[37,164]$. Clinical variants of FTD include the behavioural variant (bvFTD), language variants, e.g., semantic dementia (SD) and primary progressive aphasia (PPA), and motor variants such as corticobasal syndrome (CBS) and motor neuron disease (MND). In addition, pathological variants of FTLD include those with tau, transactive response (TAR) DNA-binding protein of $43 \mathrm{kDa}$ (TDP-43), and fused in sarcoma (FUS)-immunoreactive inclusions [37].

Discrimination between different FTLD entities is often only possible using neuropathological criteria, the majority of which are based on the morphology and molecular composition of 'signature' pathological inclusions such as neuronal cytoplasmic inclusions ( $\mathrm{NCl}$ ), neuronal intranuclear inclusions (NII), and glial inclusions (GI), the latter including oligodendroglial inclusions ('coiled bodies'), tufted astrocytes (TA), astrocytic tangles (AT), and astrocytic 'plaques' (AP) [130]. Nevertheless, the clinical features of FTD may not predict their pathology, and neuropathological features alone cannot establish a diagnosis of FTD. In addition, studies have questioned whether some members should even be classified within FTD. Hence, corticobasal degeneration (CBD) is a predo- minantly extrapyramidal motor disorder in which there is poor correlation between neuropathology and clinical syndrome [119]. In addition, there are FTD cases that exhibit a frontal lobe type of dementia but accompanied by a typical MND-type pathology not typical of any currently described FTD entity [30]. Consequently, FTD may define a group of cases, loosely united by clinical presentation, but with heterogeneous pathologies and therefore not easily classifiable according to clinico-pathological or any other criteria $[77,79,99]$.

Similar problems can be observed within CJD, which in the past was regarded as a doubtful disease entity [100]. The original CJD concept [44,88] was subsequently discarded in favour of the term 'prion disease' $[1,41]$, but there still remain problems such as overlap between CJD and other disorders, most notably with $A D[19,20,76]$. In addition, the prion-like behaviour of such pathological proteins as tau and $\alpha$-synuclein $[74,155]$ further blurs the distinction between classic prion diseases, tauopathies, and synucleinopathies.

\section{The four primary determinants}

This review proposes four key features, viz. the 'primary determinants', to describe the neuropathology of neurodegenerative disease: (1) anatomical pathways affected by the disease ('anatomy'), (2) cell types affected ('cells'), (3) primary molecular pathology of 'signature' pathological lesions ('molecules'), and (4) morphological types of neurodegeneration ('morphology'). How currently defined disorders may be related to these variables is shown in Table I.

\section{Anatomy}

One of the first demonstrations that a neurodegenerative disease was related to the breakdown of specific anatomical pathways was in $A D[45,136]$. Hence, a major feature of the pathology of $A D$ is the disruption of afferent and efferent connections between the hippocampal formation and the rest of the brain [45]. Alzheimer's disease pathology may initially affect the temporal pole, especially the entorhinal cortex (EC), before spreading to the posterior parahippocampal gyrus (PHG) and then in a stepwise fashion to the hippocampus and association cortex, leaving primary sensory areas unimpaired until later in the disease $[31,58,91,136]$. The pathology may 
Table I. Description of the major neurodegenerative diseases according to the four primary determinants

\begin{tabular}{|c|c|c|c|c|}
\hline \multicolumn{5}{|c|}{ Primary determinants } \\
\hline Disorder & Anatomy & Cells & Molecules & Morphology \\
\hline$A D$ & GC, L & N & $A \beta, 3 R / 4 R$ tau & SP, NFT \\
\hline AGD & L & $\mathrm{N}, \mathrm{A}, \mathrm{O}$ & $4 \mathrm{R}$ tau & P-NFT, NT, GR, EN, V \\
\hline CBD & FT, M, SC & $\mathrm{N}, \mathrm{A}$ & $4 \mathrm{R}$ tau & $\mathrm{NCl}$ \\
\hline CJD & GC & N & PrPsc & SP, V \\
\hline DLB & $L, C$ & N & $\alpha$-synuclein & LB, NT, EN \\
\hline FTD-MND & MC, SC & $\mathrm{N}, \mathrm{O}$ & tau & $\mathrm{NCl}, \mathrm{Gl}$ \\
\hline FTLD-TDP & FT & $\mathrm{N}, \mathrm{O}$ & TDP-43 & $\mathrm{NCl}, \mathrm{Gl}, \mathrm{V}$ \\
\hline MSA & SC & $\mathrm{O}, \mathrm{N}$ & $\alpha$-synuclein & $\mathrm{GCl}$ \\
\hline NIFID & FT, L, SC & $\mathrm{N}, \mathrm{O}$ & FUS & $\mathrm{NCl}, \mathrm{Gl}$ \\
\hline PD-Dem & L, MC, SC & N & $\alpha$-synuclein & LB, LT, LG \\
\hline PiD & FT & N & $3 R$ tau & PB, PC \\
\hline PSP & SC & $\mathrm{N}, \mathrm{A}$ & 4R tau & NFT, GI, AP \\
\hline
\end{tabular}

Disorders: $A D$ - Alzheimer's disease, $A G D$ - argyrophilic grain disease, CBD - corticobasal degeneration, CJD - Creutzfeldt-Jakob disease, DLB - dementia with Lewy bodies, FTDP-17 - fronto-temporal dementia and parkinsonism linked to chromosome 17. FTD-MND - motor neuron disease with dementia, MND - motor neuron disease, MSA - multiple system atrophy, NIFID - neuronal intermediate filament inclusion disease, PiD - Pick's disease, PD - Parkinson's disease, PSP - progressive supranuclear palsy; Anatomy: GC - general cortical, L - limbic, FT - frontotemporal, SC - subcortical; Cells: N-neurons, A - astrocytes, O - oligodendrocytes; Molecules: A - $\beta$-amyloid, PrPsc - disease form of prion protein, FUS - fused in sarcoma, TDP-43 - transactive response (TAR) DNA-binding protein of $43 \mathrm{kDa}$; Degeneration: AP-astrocytic plaque, SP-senile plaques, NCl-neuronal cytoplasmic inclusions, P-NFT-pre-tangles, NFT - neurofibrillary tangles, $N T$ - neuropil threads, $G C l$ - glial cytoplasmic inclusions, $G R$ - grains, $E N$ - abnormally enlarged neurons, $L B$ - Lewy bodies, $L T$ - Lewy neurites, $L G$ - Lewy grains, $P B$ - Pick bodies, $P C$ - Pick cells, $V$ - vacuolation

then spread among cortical gyri and to subcortical regions via cortico-cortical and cortical-subcortical pathways respectively $[5,45,136]$. This hypothesis is supported by studies of the spatial patterns of SP and NFT $[6,13]$ and of transgenic mice, in which there is selective disruption of cortico-cortical pathways [47]. Furthermore, this pattern of neurodegeneration correlates with specific neurotransmitter deficits, e.g., acetylcholinesterase-immunoreactive neurites are present at the periphery of SP, which could represent the degeneration of ascending and cortical cholinergic pathways [157].

Although many authors continue to argue that $A D$ is a distinct entity [118], it is highly heterogeneous [42,61], and cases exhibit considerable neuropathological variation $[15,19]$. Variation in the anatomical spread of disease from its origin in the MTL could account for many of these differences $[15,33,45]$. Consequently, there may be a close relationship between the distribution of the pathology and the clinical features of individual patients [67]. For example, MTL areas are relatively spared in aphasic cases of $A D$, while more severe occipito-parietal degeneration, also termed posterior cortical atrophy (PCA), is often associated with visual-spatial deficits at presentation [67].

The second commonest form of dementia is DLB, accounting for up to a quarter of all cases [120]. An essential feature of the neuropathological diagnosis of DLB is the presence of LB in the cerebral cortex and/or brain stem. Nevertheless, DLB exists in a variety of forms including neocortical, limbic [144], cerebral, and brainstem types, the neocortical subtype being the most common [85]. Many cases of DLB also exhibit ADNC $[48,70,78]$, and therefore each pathological subtype of DLB can be divided into a 'pure' or 'mixed' form based on the degree of AD co-pathology [85]. Some studies have suggested anatomical differences in the pathways affected in $A D$ and DLB. Brain glucose metabolism studies, for example, indicate that hypometabolism of the primary visual cortex (area V1) is more marked in DLB, whereas reductions in the posterior/temporal cortex, posterior cingulate gyrus, and frontal cortex occur in both AD and DLB [122]. Studies of regional cerebral blood flow (rCBF) report similar results, i.e., occipital hyperperfusion may be more frequent in DLB [110]. 
The pattern of temporal lobe atrophy may also differ between $A D$ and DLB, with less hippocampal atrophy in DLB, which could explain the preservation of memory function in DLB [26].

In FTLD, which accounts for approximately $20 \%$ of all pre-senile cases of dementia [159], the pathological changes are usually more circumscribed, affecting primarily frontal and temporal lobes [156] Nevertheless, there is often selective anatomical degeneration within this group. For example, in FTLD with transactive response (TAR) DNA-binding protein of $43 \mathrm{kDa}$ (TDP-43)-immunoreactive inclusions, atrophy of the frontal lobe and temporal pole is seen in $97 \%$ of cases, but the hippocampus and subcortical areas are less affected $[11,22,69]$. In FTD and parkinsonism linked to chromosome 17 (FTDP-17) and CBD, however, degeneration largely affects the globus pallidus and substantia nigra and is accompanied by pathological changes in the cerebral cortex and subcortical areas [143]. In MND, cortical pathology is even more restricted to the motor cortex, although the brain stem and spinal cord may also be affected [29].

A further group of disorders exhibit a predominantly subcortical pathology including MSA, PD lacking dementia, and PSP. Hence in MSA, the substantia nigra, striatum, inferior olivary nucleus, pontine nuclei, and cerebellum are affected $[18,49,105]$. In some cases, there may be progressive cerebral atrophy affecting the frontal lobes [103] and the motor/ premotor areas [168], the limbic system also being affected, principally in longer duration cases [138]. Although MSA is regarded as a single entity, two main subtypes are now recognized [72], viz., the cerebellar subtype (MSA-C) and parkinsonian subtype (MSA-P). The most consistent clinical syndrome, however, is parkinsonism, followed by cerebellar ataxia, and pyramidal tract signs [171]. Similarly, the anatomical distribution of pathological changes in PD is largely subcortical but with two clinical subtypes, viz., an 'akinetic-rigid' form with cell losses in the ventrolateral substantia nigra and related motor systems and a 'tremor-dominant' form with cell losses in the medial substantia nigra [89]. In addition, in PD with dementia (PD-Dem), which may be indistinguishable from DLB [28], there is spread of pathology to affect the cortical regions and hippocampus [24]. Progressive supranuclear palsy exhibits a more restricted form of subcortical degeneration, often sparing the cerebral cortex entirely [113]. Two clin- ical phenotypes have been identified, viz., Richardson's syndrome (RS) and PSP-parkinsonism (PSP-P), the two subtypes varying in disease duration and in tau isoforms [173]. In addition, there is loss of cholinergic innervation to the thalamus and cerebral cortex in PD, but only to the thalamus in PSP [153].

\section{Cells}

The developing pathology of neurodegenerative disease may target specific cell populations. In AD, for example, it is the larger cortical pyramidal cells that are most vulnerable, smaller neurons being more resistant [80]. In addition, labelling of damaged neurons in $A D$ is most conspicuous in lamina III of the cerebral cortex early in the disease but becomes more widespread as the pathology progresses [165]. This observation suggests a specific loss of corticocortical connections in AD [136], many of which use glutamate as neurotransmitter. The disease may then spread in either an orthograde or retrograde direction [45], gradually involving other neuronal types and eventually glial cells. In AD there is also loss of neurons which express the $75 \mathrm{kD}$ neurotrophic receptor p75NIR [174] which preferentially binds $\beta$-amyloid $(A \beta)$, and hence cells that undergo apoptosis could be mediated by this reaction. By contrast, cultured hippocampal neurons immunoreactive to the calcium-binding protein calretinin are more resistant to degeneration associated with $A \beta$ [142]. Moreover in FTLD, glutamate-immunoreactive pyramidal cells as well as calbindin D-28 $\gamma$-aminobutyric acid (GABA) neurons are lost but parvalbumin-immunoreactive cells preserved [57], consistent with loss of the cortico-cortical connections in FTLD.

A distinctive pattern of hippocampal pathology is present in CJD involving selective vulnerability of GABA neurons [75]. Hence, parvalbumin-immunoreactive neurons are severely depleted while calbindinimmunoreactive cells, which represent an early loss of inhibitory neurons, are largely preserved [75].

In FTLD, Gl can be observed in oligodendroglial cells in the hippocampus, PHG, and amygdala [134]. In addition, a fundamental cytoskeletal alteration of oligodendrocytes occurs in MSA $[18,50,170]$ resulting in the formation of characteristic 'glial cytoplasmic inclusions' (GCI) [135] which can be observed in the substantia nigra, striatum, inferior olivary nucleus, pontine nuclei, and cerebellum [105]. A close association between $\mathrm{GCl}$ and microtubules has also been 
demonstrated [129], aberrant or ectopic expression of cdk5 and MAPK leading to abnormal phosphorylation of microtubule cytoskeletal proteins and the formation of inclusions. In MSA cases with frontal lobe atrophy [103], there are cell losses in laminae $\mathrm{V} / \mathrm{VI}$ of the cerebral cortex, and $\mathrm{GCl}$ are often found in white matter. In addition, inclusions are found in the granule cell layer of the dentate gyrus and pre-frontal cortex and 'dot-like' structures or grains in the PHG [4]. The $\mathrm{GCl}$ may represent a pathological change synchronous with or preceding that of neuronal loss in MSA [84]. In addition, TA [82,102,175] are present in the motor cortex and striatum in PSP [51]. Neurons affected in PSP also appear to be functionally related, NFT occurring in interconnected extrapyramidal and oculomotor structures [151] The presence of astrocytic pathology is regarded as a diagnostic feature of PSP [82] which may distinguish the disorder from the closely related CBD $[81,109]$.

\section{Molecules}

The molecular pathology of 'signature' pathological lesions has played a highly significant role in diagnosis, the identification of new disease entities, and the development of theories of pathogenesis $[20,59]$. Studies of pathological lesions, however, reveal considerable molecular diversity [20]. In AD, for example, $A \beta$ exists in several forms, the most common being $A \beta_{42 / 43}$, found largely in SP, whereas the more soluble $A \beta_{40}$ is also found in association with blood vessels $[121,146]$ and may develop later in the disease [46]. In addition, $A \beta$ deposits may be associated with a variety of additional molecular constituents [20] including apolipoprotein E (Apo E) [176], $\alpha$-antichymotrypsin, sulphated glycosaminoglycans, and complement factors [166]. A $\beta$-immunoreactive deposits also occur in DLB, but the ratio between the isoforms may differ from AD. In DLB, the predominant form of $A \beta$ is $A \beta_{42 / 43}$, as in $A D$, but the level of $A \beta_{40}$ is reduced compared with $A D$ [117].

The majority of disorders have either tau- or $\alpha$-synuclein-immunoreactive pathology. Within the tauopathies, PiD is characterised by tau with three microtubule repeats ( $3 R$ tau), while PSP and CBD are composed of four-repeat (4R) tau [50,127]. Cellular inclusions in these disorders, however, are also associated with additional molecular constituents. Hence, $\mathrm{PB}$ in PiD are immunoreactive to ubiquitin and Alz-50 [111] and in the synucleinopathy DLB [27], LB are also reactive for intermediate filaments (IF) [65], neurofilament (NF) proteins [66], cyclin dependent kinase-5 [34], $\alpha$-B crystallin [112], and polyubiquitinated chains [86]. Furthermore, aggregates of abnormal intermediate filaments (IF) immunoreactive for $\alpha$-internexin have been identified as a component of inclusions in neuronal intermediate filament inclusion disease (NIFID), a rare subtype of FTLD [10,30,36,92]. Subsequently, 'fused in sarcoma' (FUS) protein was identified as a major pathological protein in this disorder $[23,132,177]$. In addition, a significant number of cases of FTLD are linked to the product of the transcriptional repressor gene (TARDP), viz. TDP-43 [131], suggesting that these diseases may form another molecular group, viz., the TDP-43 proteinopathies.

\section{Morphology}

There are six main types of morphological degeneration observed in neurodegenerative disease. First, extracellular protein deposits are deposited in the neuropil e.g., $A \beta$ in $A D$ [73] or the disease form of prion protein $\left(\mathrm{PrPs}^{\mathrm{sc}}\right)$ in CJD [152]. Second, intracellular protein aggregates develop as inclusions in cell bodies, nuclei, and the processes of neurons and glial cells. These include the various types of $\mathrm{NCl}$, including NFT in AD, LB in PD and DLB [120], $P B$ in PiD [111], and tau-reactive neurons in CBD [81]. In addition, $\mathrm{Gl}$, including the $\mathrm{GCl}$ characteristic of MSA [135], occur in a variety of disorders including FTLD-TDP, AGD, and CBD. Third, some disorders exhibit extensive neuropil threads (NT) or dystrophic neurites (DN) in specific brain regions such as in FTLD-TDP [22] and PD-Dem [24,149]. Fourth, disorders such as PD-Dem also possess Lewy grains (LG) which are $\alpha$-synuclein-immunoreactive and which resemble the tau-reactive argyrophilic grains (AG) commonly observed in AGD [32,163,178], AD [148], and elderly, cognitively normal brains [52,94].

Fifth, abnormally enlarged neurons (EN), defined as having an irregularly enlarged or swollen cell body in which the largest diameter of the perikarya is at least three times the nuclear diameter [9], are a common feature of many disorders including AD [64], PiD, CBD, and AGD [163]. Enlarged neurons are also present in CJD, especially in cases with severe white matter degeneration $[17,96,104]$. In PSP, however, EN are less numerous and where present confined to 
limbic regions [124,167]. There are also different types of EN. Hence, in PiD and CBD $[14,16]$, there is uniform swelling of the neuronal perikaryon resulting in the characteristic 'ballooned' neurons, these cells being referred to as either Pick cells (PC) in PiD or ballooned neurons (BN) in CBD [126]. In addition, there are swollen achromatic neurons (SAN) in which the cell body is more irregularly enlarged, the Nissl substance uniformly pale, powdery, and eosinophilic, and the cell nucleus displaced to the cell margin [113]. Finally, there are swollen cells which occur in inherited neurovisceral disorders such as Niemann-Pick disease type-C in which swelling of the cell is associated with abnormalities in lipid storage $[35,53]$. Hence, EN in neurodegenerative disease lack specificity to any particular disease [64] but may indicate particular types of pathological change. Ballooned neurons occur after infarction and could represent an attempt at regeneration following axonal damage [3]. Enlarged neurons could also be a stress response since many swollen neurons are immunoreactive to $\alpha$-B-crystallin induced by neuronal stress and which may have a protective function [123]. In addition, peripheral nerve transection, which separates nerve cells from their targets, may also lead to EN [141].

Sixth, significant vacuolation is a feature of many disorders, most notably CJD ('spongiform change') [152], but also to varying degrees AD, DLB, and FTLD, the latter often present as microvacuolation in superficial cortical laminae [22]. In the sporadic subtype of CJD (SCJD), clustering of vacuoles occurs in association with either neuronal perikarya or PrPsc deposits [17], while in the cerebellum of the variant subtype of CJD (VCJD), clusters of vacuoles in the molecular layer are negatively correlated with surviving Purkinje cells [21]. Hence, the degree of vacuolation could be an indication of the extent of neuronal loss in a region.

\section{Independence of primary determinants}

An important consideration is whether the four primary determinants are independent variables. If variables are inter-correlated, however, degeneration of a specific anatomical pathway may predict cell type affected, molecular pathology, or type of neurodegeneration. If this hypothesis is correct, then only certain combinations of anatomy, cells, molecules, and morphology would define neurodegenerative disease. Hence, in AD, which has tau-immunoreactive NFT, LB may also be present, and there is a strong correla- tion between the presence of cortical $\alpha$-synuclein-immunoreactive $L B$ and degeneration of the substantia nigra [97]. In addition, in FAD linked to the $A P P_{717}$ mutation, extrapyramidal features were present in all members of a single family and LB were present in a proportion of individuals [147]. Moreover, cortical LB in DLB are composed of intermediate filaments (IF) and a granular matrix, while brain stem LB have an electron-dense core and radially oriented filaments [65]. These results suggest that it is degeneration of a specific anatomical pathway, e.g., the extrapyramidal system, that could determine the molecular pathology, e.g., in this case, $\alpha$-synuclein-immunoreactive LB. However, there is no specific relationship between grains (GR) and molecular pathology, GR being $\alpha$-synuclein- or tau-immunoreactive in PD-Dem [149] and AGD $[32,163,178]$ respectively.

In AD, cortical and subcortical NFT are composed of morphologically similar paired helical filaments (PHF), but cortical and subcortical PHF have a different molecular composition [161]. In addition, within the tauopathies, diseases may have morphologically similar tau-immunoreactive inclusions [56] but exhibit regional differences in distribution, especially in PSP, PD and CBD, which could be associated with different types of tau abnormality. Furthermore, in Niemann-Pick disease, the clinical spectrum of the disease is heterogeneous, rapid progression being associated with axonal spheroids and slow progression with NFT and neuronal dystrophy [158]. The NFT have a similar composition to those of AD but a different morphology reflecting their regional origin. In addition, frontal lobe atrophy could occur in both PSP and DLB associated with either NFT or LB respectively [43]. Differences in the neuronal population affected in the frontal cortex or in patient genotype could account for these differences. Positive correlations have also been observed among the densities of LB, LN, and LG in PD-Dem, suggesting that they could result from degeneration of the same neurons, LB aggregating in cell bodies and $L N$ and $L G$ in adjacent neurites and synapses respectively [24].

Studies that directly correlate a molecular pathology with loss of a specific cell type are rare. However, McKenzie et al. [115] found that specific areas of MTL secreted large quantities of amyloid precursor protein (APP), and that more APP-immunoreactive neurons were found in these areas in head injury patients, which could explain the high density of SP in the temporal lobe in $A D$ [12] and the subsequent 
spread of pathology [45]. In PSP, tau mRNA isoforms containing 4R tau are increased in the brainstem but not in the frontal cortex or cerebellum, which could predict the eventual anatomical distribution of these inclusions [40].

\section{Weighting of primary determinants}

Of the four primary determinants, molecular pathology has had the most profound impact over the last 25 years $[20,54]$. Should therefore this variable be regarded as the most fundamental? Classification based on molecular pathology, however, is often at variance with more traditional concepts based on anatomy. For example, AD and DLB are closely related and overlap extensively in clinical and pathological features [20], but AD is a tauopathy and DLB a synucleinopathy and therefore different at the molecular level. In addition, PSP is a tauopathy, but also an example of 'atypical parkinsonism' and therefore clinically related to the synucleinopathies PD, MSA, and DLB [154]. Recent research has criticised the concentration on 'signature' pathological lesions and their

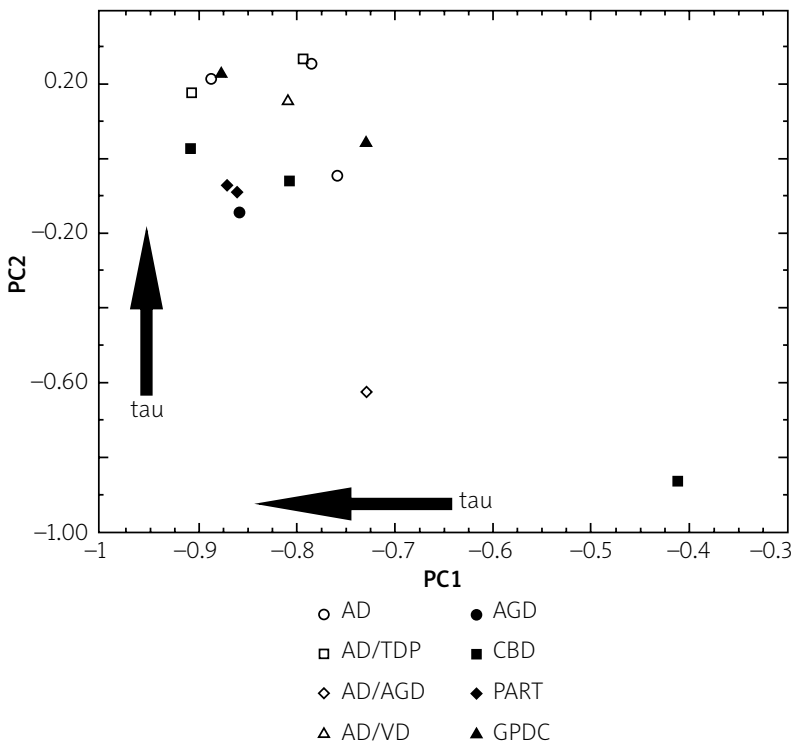

Fig. 1. Principal components analysis of 15 tauopathy cases (AD - Alzheimer's disease, AGD - argyrophilic grain disease, $C B D$ - corticobasal degeneration, GPDC - Guamanian Parkinson's disease dementia complex [GPDC], PART - primary agerelated tauopathy) using variables derived from the four primary determinants. A plot of the cases in relation to the first two principal components (PC) 1 and 2 (Armstrong, unpublished data). molecular determinants and has questioned whether this emphasis has been detrimental to the study of neurodegenerative disease as a whole [39]. Hence, given current uncertainties regarding which variables are 'important' or 'fundamental', it is suggested that all four determinants should be given equal weight.

\section{Application}

An important practical question concerns what categories of anatomy, cells, molecules, and neurodegeneration should be used to define the descriptive axes. The multiplicity of possible defining variables suggests the use of a multivariate data analysis method such as principal components analysis (PCA) $[15,22]$. Principal components analysis simplifies a description of cases based on multiple variables by selecting two or three axes which describe sources of maximum variation in the data, i.e., 'the principal components' (PC). Hence, a PCA enables the degree of similarity and dissimilarity between cases to be studied based on quantitative estimates of their neuropathological characteristics $[15,22]$. The result of a PCA is a scatter plot of cases in relation to the PC in which the distance between cases reflects their similarity or dissimilarity, based on the defining histological features. Each PC therefore accounts for a proportion of the total variance in the data, PC1 accounting for the greatest amount of the variance and remaining PCs for diminishing amounts of the remaining variance. Such a system appears to have the requisite multivariate geometry and simplicity necessary to provide a possible framework for describing neurodegenerative disease. The following examples are based on relatively small numbers of cases and a restricted range of descriptive variables to illustrate the methodology.

\section{Example 1: Investigating the relationships between closely related tauopathies}

The objective was to investigate similarities and differences among 15 closely related tauopathy cases traditionally classified as AD, AGD, CBD, Guamanian Parkinson's disease dementia complex (GPDC), or primary age-related tauopathy (PART). The defining variables include: (1) anatomy: frontal and temporal lobes and substantia nigra, (2) cells: neurons, astrocytes, oligodendrocytes, (3) molecules: tau, A $\beta$, and TDP-43, and (4) morphology: NCl, NT, GR, AT, GI, SP, EN, and 
vacuolation. A plot of the 15 cases in relation to the first two principal components is shown in Figure 1.

Several features are evident from this plot. First, the majority of cases form a single cluster towards the upper left of the plot, the two remaining cases (AD/AGD, CBD) being more atypical. Second, within the main cluster, there is no obvious clustering of cases with similar co-pathology such as AD or TDP-43, although the two PART cases do occupy closely related positions. Third, several neuropathological variables are correlated with the factor loadings of the cases on the PC but overall there is a general increase in tau pathology with increasingly negative loadings on PC1 and positive loadings on PC2. Hence, if a new tauopathy case were to be added to this analysis, it would be possible to determine: (1) from its location, whether the new case was a typical or an atypical tauopathy, (2) the affinity of the new case relative to previous cases, and (3) the relative location of the case along a continuum of severity of tau pathology.

\section{Example 2: Investigation of subtypes of FTLD-TDP}

The second example is a study of neuropathological heterogeneity within FTLD with TDP-43immunoreactive pathology (FTLD-TDP). These cases have a complex neuropathology comprising $\mathrm{NCl}$, NII, GI, and DN. Four pathological subtypes of FTLDTDP have been proposed $[37,114,150]$ based on the type and regional distribution of the various types of inclusion. Hence, type 1 cases (Mackenzie-type 2) are characterized by long DN in superficial cortical laminae with few or no NCl or NII, type 2 (Mackenzietype 3) by numerous $\mathrm{NCl}$ in superficial and deep cortical laminae with infrequent DN and sparse or no NII, type 3 (Mackenzie-type 1) by pathology predominantly affecting the superficial cortical laminae with numerous $\mathrm{NCl}, \mathrm{DN}$ and varying numbers of NII, and type 4 by numerous $\mathrm{NII}$, and infrequent $\mathrm{NCl}$ and DN especially in neocortical areas. The defining variables were: (1) anatomy: frontal and temporal lobes, (2) cells: neurons and oligodendroglia, (3) molecules: TDP-43, and (4) neurodegeneration: $\mathrm{NCl}, \mathrm{NII}, \mathrm{DN}$, and Gl. Hence, quantitative estimates of density of TDP-43-immunoreactive neuronal and glial inclusions were made in frontal and temporal regions of 94 cases of FTLD-TDP [22]. A PCA of the data is shown in Figure 2 and shows that cases representing the four subtypes exhibit considerable overlap, subtypes 1 and 4 being the most distinctive and located towards the bottom and top of the plot respectively. Cases of subtype 2 and 3 were less distinct, with a greater degree of overlap. Hence, new cases could be added to the analysis over time and their location relative to $P C 1$ and $P C 2$, and therefore to all previous cases, established. Location of a new case would suggest to which subtype the case may belong. Hence, in Figure 2, new case $A$ would be most likely to be an example of subtype 1 and case $B$ of subtype 4. New cases $C$ and D are more difficult to classify, although it is probable that they have more affinity with subtypes 2 and 3 .

\section{Further applications}

More extensive applications of the methodology could include all cases of neurodegenerative disease from a single neuropathological centre and ultimately from several contributing centres. A major problem in attempting to apply this approach on a larger scale, however, is the lack of comparative quantitative data of sufficient scope, detail, quality, and consistency to define all possible cases. Most quan-

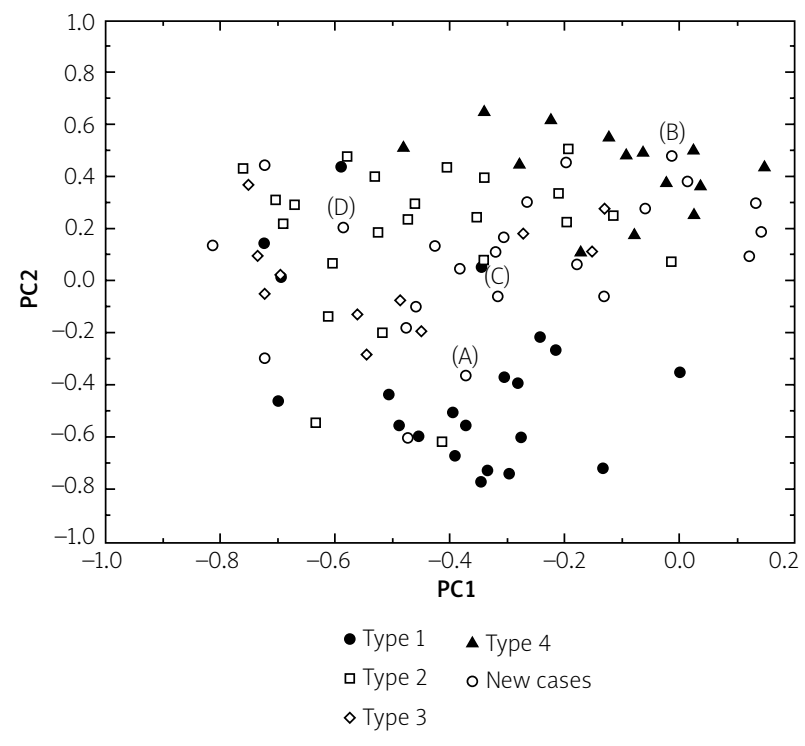

Fig. 2. Principal components analysis of 94 cases of frontotemporal lobar degeneration with TDP proteinopathy (FTLD-TDP) based on the densities of TDP-43 immunoreactive neuronal and glial inclusions in frontal and temporal cortex. Identified on the plot are the subtypes of disease based on the system of Cairns et al. (2007). Cases marked A, B, C, D are new cases added to the existing plot (data from Armstrong et al. 2010). 
titative studies of a disorder quantify only signature pathological lesions [11], while others confine observations to a restricted number of anatomical regions or cell types, whereas all aspects of anatomy, cells, molecules, and morphology would need to be measured in each case. Nevertheless, the recent detailed comparative study of a large number of cases of ten neurodegenerative diseases, albeit using semi-quantitative data [25], demonstrates that it is feasible to collect comparative data across a large number of cases and disorders, enabling a descriptive system to be developed based on the four primary determinants.

\section{Conclusions}

This review proposes that four primary determinants could be used as the basis of a system to describe the neuropathology of neurodegenerative disease and which can take into account disease heterogeneity, overlap, and the presence of multiple pathologies. Such an approach has a number of advantages. First, it could describe all cases of neurodegenerative disease, not just those that may fit more traditional concepts. Second, it would emphasise the continuous nature of neurodegenerative disease by incorporating disease heterogeneity and overlap to their true extent $[8,19]$. Third, it would remove the necessity to classify new cases within an existing system, especially those which exhibit more complex multiple pathologies, as each case would be regarded as unique and would be located within a space defined by the primary determinants. Fourth, it potentially reveals the similarities and differences between cases included in the analysis, emphasising that common pathological mechanisms may be involved in different disorders. A major limiting factor in applying such a system on a large scale, however, is the current lack of detailed quantitative data of sufficient quality across cases and disorders [25].

\section{Disclosure}

Author reports no conflict of interest.

\section{References}

1. Aguzzi A, Weissmann C. Prion research: the next frontier. Nature 1997; 389: 795-798.

2. Alzheimer A. Uber eine eigenartige Erkrankung der Hirnrinde. Allge Zeitsch Psychiatr und Psychisch-Gerich Med 1907; 64: 146-148.
3. Aoki K, Uchihara T, Nakamura A, Komori T, Arai N, Mizutani T. Expression of apolipoprotein $\mathrm{E}$ in ballooned neurons: comparative immunohistochemical study in neurodegenerative disorders and infarctions. Acta Neuropathol 2003; 106: 436-440.

4. Arai N, Papp MI, Lantos PL. New observations on ubiquinated neurons in the cerebral cortex of multiple system atrophy (MSA). Neurosci Lett 1994; 182: 197-200.

5. Armstrong RA. Alzheimer's disease: are cellular neurofibrillary tangles linked to $\beta / A 4$ formation at projection sites? Neurosci Res Commun 1992; 11: 171-178.

6. Armstrong RA. Is the clustering of neurofibrillary tangles in Alzheimer's patients related to the cells of origin of specific corticocortical projections? Neurosci Lett 1993; 160: 57-60.

7. Armstrong RA. The interface between Alzheimer's disease, normal aging and related disorders. Current Aging Science 2008; 1: $122-132$.

8. Armstrong RA. On the classification of neurodegenerative disorders: discrete entities, overlap or continuum? Folia Neuropathol 2012; 50: 201-218.

9. Armstrong RA. A quantitative study of abnormally enlarged neurons in cognitively normal brain and neurodegenerative disease. Clin Neuropathol 2013; 32: 128-134.

10. Armstrong RA, Cairns NJ. Topography of $\alpha$-internexin-positive neuronal aggregates in 10 patients with neuronal intermediate filament inclusion disease. Eur J Neurol 2006; 13: 528-532.

11. Armstrong RA, Cairns NJ. Comparative quantitative study of 'signature' pathological lesions in the hippocampus and adjacent gyri of twelve neurodegenerative disorders. J Neural Transm 2015; 122: 1355-1367.

12. Armstrong RA, Myers D, Smith CUM. The distribution of senile plaques, neurofibrillary tangles and $\beta / A 4$ protein in the hippocampus in Alzheimer's disease. Neurosci Res Commun 1992; 10: 87-94

13. Armstrong RA, Myers D, Smith CUM. The spatial patterns of $\beta / A 4$ deposit subtypes in Alzheimer's disease. Acta Neuropathol 1993; 86: 36-41.

14. Armstrong RA, Cairns NJ, Lantos PL. The spatial pattern of Pick bodies, Pick cells and Alzheimer disease pathology in Pick's disease. Neuropathology 1999; 19: 64-70.

15. Armstrong RA, Nochlin D, Bird TD. Neuropathological heterogeneity in Alzheimer's disease: a study of 80 cases using principal components analysis. Neuropathology 2000; 1: 31-37.

16. Armstrong RA, Cairns NJ, Lantos PL. A quantitative study of the pathological lesions in the neocortex and hippocampus of 12 patients with corticobasal degeneration. Exp Neurol 2000; 163: 348-356.

17. Armstrong RA, Lantos PL, Cairns NJ. Spatial correlations between the vacuolation, prion protein deposits, and surviving neurons in the cerebral cortex in sporadic Creutzfeldt-Jakob disease. Neuropathology 2001; 21: 266-271.

18. Armstrong RA, Cairns NJ, Lantos PL. A quantitative study of the pathological changes in ten patients with multiple system atrophy (MSA). J Neural Transm 2004; 111: 485-495.

19. Armstrong RA, Cairns NJ, Lantos PL. Overlap between neurodegenerative disorders. Neuropathology 2005; 25: 111-124. 
20. Armstrong RA, Lantos PL, Cairns NJ. What determines the molecular composition of abnormal protein aggregates in neurodegenerative disease? Neuropathology 2008; 28: 351-365.

21. Armstrong RA, Ironside J, Lantos PL, Cairns NJ. A quantitative study of the pathological changes in the cerebellum of 15 cases of variant Creutzfeldt-Jakob disease. Neuropathol Appl Neuro 2009; 35: 36-45.

22. Armstrong RA, Ellis W, Hamilton RL, Mackenzie IRA, Hedreen J, Gearing M, Montine T, Vonsattel J-P, Head E, Lieberman AP, Cairns NJ. Neuropathological heterogeneity in frontotemporal lobar degeneration with TDP-43 proteinopathy: a quantitative study of 94 cases using principal components analysis. J Neural Transm 2010; 117: 227-239.

23. Armstrong RA, Gearing M, Bigio EH, Cruz-Sanchez FF, Duyckaerts C, Mackenzie IRA, Perry RH, Skullerud K, Yokoo H, Cairns NJ. The spectrum and severity of FUS-immunoreactive inclusions in the frontal and temporal lobes of ten cases of neuronal intermediate filament inclusion disease. Acta Neuropathol 2011; 121: 219-228.

24. Armstrong RA, Kotzbauer PT, Perlmutter JS, Campbell MC, Hurth KM, Schmidt RE, Cairns NJ. A quantitative study of $\alpha$-synuclein pathology in fifteen cases of dementia associated with Parkinson disease. J Neural Transm 2014; 121: 171-181.

25. Arnold SE, Toledo JB, Appleby DH, Xie SX, Wang LS, Baek Y, Wolk DA, Lee EB, Miller BL, Lee VM, Trojanowski JQ. Comparative survey of the topographical distribution of signature molecular lesions in major neurodegenerative disease. J Comp Neurol 2013; 521: 4339-4353.

26. Barber R, McKeith IG, Ballard C, Gholkar A, O’Brien JT. A comparison of medial and lateral temporal lobe atrophy in dementia with Lewy bodies and Alzheimer's disease: magnetic resonance imaging volumetric study. Dement Geriatr Cogn 2001; 12: 198-205.

27. Bayer TA, Jakala P, Hartmann T, Harvas L, McLean C, Culvenor JG, Li QX, Masters CL, Falkai P, Beyreuther K. Alpha-synuclein accumulates in Lewy bodies in Parkinson's disease and dementia with Lewy bodies but not in Alzheimer's disease beta amyloid plaque cores. Neurosci Lett 1999; 266: 213-216.

28. Berg D, Postuma RB, Bloem B, Chan P, Dubois B, Gasser T, Goetz CG, Halliday GM, Hardy J, Lang AE, Litvan I, Marek K, Obeso J, Oertel W, Olanow CW, Poewe W, Stern M, Deuschi G. Time to redefine PD? Introductory statement of the MDS Task Force on the definition of Parkinson's disease. Movement Disord 2014; 29: 454-462

29. Bergmann M, Kuchelmeister K, Schmid KW, Kretzschmar HA, Schroder R. Different variants of FTD: a neuropathological and immunohistochemical study. Acta Neuropathol 1996; 92: 170179.

30. Bigio EH, Lipton AM, White CL, Dickson DW, Hirano A. Frontotemporal dementia and motor neurone degeneration with neurofilament inclusion bodies: additional evidence for overlap between FTD and ALS. Neuropathol Appl Neuro 2003; 29 239-253.

31. Braak H, Braak E, Bohl J. Retrosplenial region involvement in Alzheimer's disease. Neurodegeneration 1992; 1: 53-57.
32. Braak H, Braak E. Argyrophilic grain disease: frequency of occurrence in different age categories and neuropathologic diagnostic criteria. J Neural Transm 1998; 105: 801-819.

33. Braak H, Alafuzoff I, Arzberger T, Kretzschmar H, Del Tredici K. Staging of Alzheimer disease-associated neurofibrillary pathology using paraffin sections and immunocytochemistry. Acta Neuropathol 2006; 112: 389-404.

34. Brion JP, Couk AM. Cortical and brain stem type Lewy bodies are immunoreactive for the cyclin dependent kinase-5. Am J Pathol 1995; 147: 1465-1476.

35. Bu B, Li J, Davies P, Vincent I. Deregulation of cdk5, hyperphosphorylated and cytoskeletal pathology in the Niemann-Pick type C murine model. J Neurosci 2002; 22: 6515-6525.

36. Cairns NJ, Perry RH, Jaros E, Burn D, McKeith IG, Lowe JS, Holton J, Rossor MN, Skullerud K, Duyckaerts C, Cruz-Sanchez FF, Lantos PL. Patients with a novel neurofilamentopathy: dementia with neurofilament inclusions. Neurosci Lett 2003; 341: 177-180.

37. Cairns NJ, Bigio EH, Mackenzie IRA, Neumann M, Lee VMY, Hatanpaa KJ, White CL, Schneider JA, Grinberg LT, Halliday G, Duyckaerts C, Lowe JS, Holm IE, Tolnay M, Okamoto K, Yokoo H, Murayama S, Woulfe J, Munoz DG, Dickson DW, Ince PG, Trojanowski JQ, Mann DMA. Neuropathologic diagnostic and nosological criteria for frontotemporal lobar degeneration: consensus of the Consortium for Frontotemporal Lobar Degeneration. Acta Neuropathol 2007; 114: 5-22.

38. Caselli RJ. Asymmetric cortical degeneration syndrome. Curr Opin Neurol 1996; 9: 276-280.

39. Castellani RJ, Perry G. Pathogenesis and disease-modifying therapy in Alzheimer's disease: the flat line of progress. Arch Med Res 2012; 43: 694-698.

40. Chambers CB, Lee JM, Troncuso JC, Reich S, Muma NA. Overexpression of four-repeat tau in RNA isoforms in progressive supranuclear palsy but not in Alzheimer's disease. Ann Neurol 1999; 46: 325-332.

41. Chesebro B. BSE and prions: uncertainties about the agent. Science 1998; 279: 42-43.

42. Chui HC, Teng EL, Henderson VW, Moy AC. Clinical subtypes of dementia of the Alzheimer type. Neurology 1985; 35: 15441550.

43. Cordato NJ, Halliday GM, Harding AJ, Hely MA, Morris JGL. Regional brain atrophy in progressive supranuclear palsy and Lewy body disease. Ann Neurol 2000; 47: 718-728.

44. Creutzfeldt HG. Uber eines eigenartige herd-formige Erkrankung des Zentralnervensystems. In: Histologische und Histopathologische Arbeiten uber die Grosshirnrinde. Nissl F, Alzheimer A (eds.). Gustav Fisher, Jena 1921; pp. 1-48.

45. De Lacoste $M$, White CL. The role of cortical connectivity in Alzheimer's disease: a review and model system. Neurobiol Aging 1993; 14: 1-16.

46. Delacourte A, Sergeant N, Champain D, Wattez A, Maurage CA, Lebert F, Pasquier F, David JP. Nonoverlapping but synergetic tau and amyloid precursor protein pathologies in sporadic Alzheimer's disease. Neurology 2002; 59: 398-407.

47. Delatour B, Blanchard V, Pradier L, Duyckaerts C. Alzheimer pathology disorganises cortico-cortical circuitry: direct evidence from a transgenic mouse model. Neurobiol Dis 2004; 16: 41-47. 
48. Dickson DW, Ruan D, Crystal H, Mark MH, Davies P, Kress Y, Yen SH. Hippocampal degeneration differentiates diffuse Lewy body disease (DLBD) from Alzheimer's disease: light and electron microscope immunocytochemistry of CA2-3 neurites specific to DLBD. Neurology 1991; 41: 1402-1409.

49. Dickson DW, Lin WL, Liu WK, Yen SH. Multiple system atrophy: a sporadic synucleinopathy. Brain Pathol 1999; 9: 721-732.

50. Dickson DW, Liu WK, Hardy J, Farrer M, Melita N, Vitti R, Mark M, Zimmermann T, Gothe L, Sage J, Sima A, Damato C, Abin R, Gilman S, Yen SH. Widespread alterations of alpha-synuclein in multiple system atrophy. Am J Pathol 1999; 155: 1241 1251.

51. Dickson DW. Neuropathological differentiation of progressive supranuclear palsy and corticobasal degeneration. J Neurol 1999; 246: 6-15.

52. Ding ZT, Wang Y, Jiang YP, Hashizume Y, Yoshida M, Mimuro M, Inagaki T, Iwase T. Characteristics of alpha-synucleinopathy in centenarians. Acta Neuropathol 2006; 111: 450-458.

53. Distl R, Treiber-Held S, Albert F, Meske V, Harzer K, Ohm TG. Cholesterol storage and tau pathology in Nieman-Pick type C disease in the brain. J Pathol 2003; 200: 104-111.

54. Drouet B, Pincon-Raymond M, Chambaz J, Pillot T. Molecular basis of Alzheimer's disease. Cell Mole Life Sci 2000; 57: 705715.

55. Feany MB, Dickson DW. Neurodegenerative disorders with extensive tau pathology: a comparative study and review. Ann Neurol 1996; 40: 139-148.

56. Feany MB, Mattiace LA, Dickson DW. Neuropathological overlap of progressive supranuclear palsy, Pick's disease and corticobasal degeneration. J Neuropathol Exp Neuro 1996; 55: 53-67.

57. Ferrer I. Neurons and their distribution in frontotemporal dementia. Dement Geriatr Cogn 1999; 10: 55-60.

58. Filey CM, Kleinschidtdemasters BK, Gross KF. Non-Alzheimer frontotemporal dementia: a neurobehavioural and pathological study. Clin Neuropathol 1994; 13: 109-116.

59. Forman MS, Trojanowski JQ, Lee VM-Y. Neurodegenerative dis eases: a decade of discoveries paves the way for therapeutic breakthroughs. Nat Med 2004; 10: 1055-1063.

60. Forstl H, Baldwin B. Pick and the focal brain atrophies. Fortschr Neurol Psych 1994; 62: 345-355.

61. Forstl H, Fischer P. Diagnostic confirmation, severity and subtypes of Alzheimer's disease. Eur Arch Psychiatry Clin Neurosci 1994; 244: 252-260.

62. Forstl H. Alzheimer's disease: the size of the problem, clinical manifestation and heterogeneity. J Neural Transm 1998; 54: 1-8.

63. Forstl H. The Lewy body variant of Alzheimer's disease: clinical, pathophysiological and conceptual issues. Eur Arch Psych Clin Neurol 1999; 249: 64-67.

64. Fujino Y, Delucia MW, Davies P, Dickson DW. Ballooned neurons in the limbic lobe are associated with Alzheimer-type pathology and lack diagnositic specificity. Neuropathol Appl Neuro 2004; 30: 676-682.

65. Fukuda T, Tanaka J, Watabe K, Numoto RT, Minamitani M. Immunohistochemistry of neuronal inclusions in the cerebral cortex and brain stem in Lewy body dementia. Acta Pathol Japon 1993; 43: 545-551.
66. Gai WP, Blumbergs PC, Blessing WW. Microtubule-associated protein- 5 is a component of Lewy bodies and Lewy body neurites in the brainstem and forebrain regions affected in Parkinson's disease. Acta Neuropathol 1996; 91: 78-81.

67. Galton CJ, Patterson K, Xuereb JH, Hodges JR. Atypical and typical presentations of Alzheimer's disease: a clinical, neuropsychological, neuroimaging and pathological study of 13 cases. Brain 2000; 123: 484-498.

68. Garraux G, Salmon E, Degueldre C, Lemaire C, Frank G. Medial temporal lobe metabolic impairment in dementia associated with motor neuron disease. J Neurol Sci 1999; 168: 145-150.

69. Giannakopoulos P, Hof PR, Bouras C. Dementia lacking distinctive histopathology: clinicopathological evaluation of 32 cases. Acta Neuropathol 1995; 89: 346-355.

70. Gibb WR, Luthert PJ, Janota I, Lantos PL. Cortical Lewy body dementia: clinical features and classification. J Neurol Neurosurg Psychiatry 1989; 52: 185-192.

71. Gilman S, Low PA, Quinn N, Albanese A, Ben-Schlomo Y, Fowler CJ, Kaufmann H, Klockgether T, Lang AE, Lantos PL, Livan I, Mathias CJ, Oliver E, Roberstson D, Schatz I, Wenning GK. Consensus statement on the diagnosis of multiple system atrophy. J Auton Nerv Syst 1998; 74: 189-192.

72. Gilman S, Wenning GJK, Low PA, Brooks DJ, Mattias CJ, Trojanowski JQ, Wood NW, Colosima C, Durr A, Fowler CJ, Kaufmann H, Klockgether T, Lees A, Poese W, Quinn N, Revesz T, Robertson D, Sandroni T, Seppi K, Vidailhet M. Second consensus statement on the diagnosis of multiple system atrophy. Neurology 2008; 71: 670-676.

73. Glenner GG, Wong CW. Alzheimer's disease and Down's syndrome: sharing of a unique cerebrovascular amyloid fibril protein. Biochem Bioph Res Commun 1984; 122: 1131-1135.

74. Goedert M, Clavaguera F, Tolnay M. The propagation of prionlike protein inclusions in neurodegenerative diseases. Trends Neurosci 2010; 33: 317-325.

75. Guentchev M, Hainfellner JA, Trabattori GR, Budka H. Distribution of parvalbumin-immunoreactive neurons in brain correlates with hippocampal and temporal cortical pathology in Creutzfeldt-Jakob disease. J Neuropath Exp Neurol 1997; 56: 1119-1124

76. Hainfellner JA, Aanschutz J, Jellinger K, Liberski PP, Gullotta F, Budka H. Coexistence of Alzheimer type neuropathology in Creutzfeldt-Jakob disease. Acta Neuropathol 1998; 96: 116-122.

77. Hamilton RL, Bouser R. Alzheimer's disease pathology in amylotrophic lateral sclerosis. Acta Neuropathol 2004; 107: 515-522.

78. Harrington CR, Perry RH, Perry EK, Hurt J, McKeith JG, Roth M, Wischik CM. Senile dementia of the Lewy body type and Alzheimer type are biochemically distinct in terms of paired helical filaments and hyperphosphorylated tau proteins. Dementia 1994; 5: 215-228.

79. Hodges JR, Davies RR, Xureb JH, Casey B, Broe M, Bak TH, Kril JJ, Halliday GM. Clinicopathological correlates in frontotemporal dementia. Ann Neurol 2004; 56: 399-406.

80. Hof PR, Morrison JH. Neocortical neuronal subpopulations labelled by a monoclonal antibody to calbindin exhibit differential vulnerability in Alzheimer's disease. Exp Neurol 1991; 111: 293-301. 
81. Ikeda K. Basic pathology of corticobasal degeneration. Neuropathology 1997; 17: 127-133.

82. Ikeda K, Akiyama H, Kondo H, Haga C, Tanno E, Tokuda T, Ikeda S. Thorn-shaped astrocytes: possibly secondarily induced tau-positive glial fibrillary tangles. Acta Neuropathol 1995; 90: 620-625.

83. Ikeda K, Tsuchiya K. Motor neuron disease group accompanied by inclusions of unidentified protein signalled by ubiquitin. Neuropathology 2004; 24: 117-124.

84. Inoue M, Yagishita S, Ryo M, Hasegawa K, Amano N, Matsushita $M$. The distribution and dynamic density of oligodendroglial cytoplasmic inclusions $(\mathrm{GCl})$ in multiple system atrophy: a correlation between the density of $\mathrm{GCl}$ and the degree of involvement of striatonigral and olivopontocerebellar systems. Acta Neuropathol 1997; 93: 585-591.

85. Iseki E, Marin W, Kosaka K, Kato M, Yamamoto T, Ueda K. Clinicopathological multiplicity of dementia with Lewy bodies. Neuropathology 1999; 19: 386-394.

86. Iwatsubo T, Yamaguchi H, Fujinuro M, Yokosawa H, Ihara Y, Trojanowski JQ, Lee VMY. Purification and characterisation of Lewy bodies from the brains of patients with diffuse Lewy body dis ease. Am J Pathol 1996; 148: 1517-1529.

87. Jackson $M$, Lowe J. The new neuropathology of degenerative frontotemporal dementias. Acta Neuropathol 1996; 91: 127-134.

88. Jakob A. Uber eigenartige Erkrankungen des Zentralnervensys tems mit bemerkenswerten anatomischen Befunden (spastische Pseudosklerose-Encephalomyelopathic mit disseminierten Degenerationsherden). Dtsch Z Nervenheilk 1921; 70 132-146.

89. Jellinger KA, Bancher C. Neuropathology of Alzheimer's disease: a critical update. J Neural Transm 1998; 54: 77-95.

90. Jellinger KA. Recent developments in the pathology of Parkinson's disease. J Neural Transm (Suppl) 2002; 62: 347-376.

91. Jobst KA, Smith AD, Szatmari M, Molyneux A, Esiri MM, King E, Smith A, Jaskowski A, McDonald B, Wald N. Detection in life of confirmed Alzheimer's disease using a simple measurement of medial temporal lobe atrophy by computed tomography. Lancet 1992; 340: 1179-1183.

92. Josephs KA, Holton JL, Rossor MN, Braendgaard H, Ozawa T, Fox NC, Petersen RC, Pearl GS, Ganguly M, Rosa P, Laursen H, Parisi JE, Waldemar G, Quinn NP, Dickson DW, Revesz T. Neurofilament inclusion body disease: a new proteinopathy? Brain 2003; 126: 2291-2303.

93. Josephs KA, Knopman DS, Whitwell JL, Boeve BF, Parisi JE, Petersen RC, Dickson DW. Survival in the two variants of tau negative FTLD: FTLD-U versus FTLD-MND. Neurology 2005; 65: 645-647.

94. Josephs KA, Whitwell JL, Parisi JE, Knopman DS, Boeve BF, Geda YE, Jack CR, Petersen RC, Dickson DW. Argyrophilic grains: a distinct disease or an additive pathology? Neurobiol Aging 2008; 29: 566-573

95. Kalaria RN. Comparison between Alzheimer's disease and vas cular dementia: implications for treatment. Neurol Res 2003; 25: 661-664

96. Kato S, Hirano A, Umahara T, Wena JF, Herz F, Ohama E. Ultrastructural and immunohistochemical studies on ballooned cortical neurons in Creutzfeldt-Jakob disease: expression of
alpha-B-crystallin, ubiquitin and stress response protein-27. Acta Neuropathol 1992; 84: 443-448.

97. Kazee AM, Han LY. Cortical Lewy bodies in Alzheimer's disease. Arch Pathol Lab Med 1995; 119: 448-453.

98. Kertesz A, Kalvach P. Arnold Pick and German neuropsychiatry in Prague. Arch Neurol 1996; 53: 935-938.

99. Kertesz A, Davidson W, Munoz DG. Clinical and pathological overlap between fronto-temporal dementia, primary progressive aphasia and corticobasal degeneration: The Pick complex. Dement Geriatr Cogn 1999; 10: 46-49.

100. Kirschbaum WR. Jakob-Creutzfeldt Disease (spastic psuedosclerosis, A. Jakob; Heidenhain syndrome; subacute spongiform encephalopathy). Elsevier, New York 1968.

101. Knopman DS. An overview of common non-Alzheimer dementias. Clin Geriatr Med 2001; 17: 281-301.

102. Komori T. Tau positive glial inclusions in progressive supranuclear palsy, corticobasal degeneration and Pick's disease. Brain Pathol 1999; 9: 663-679.

103. Konogaya M, Sakai M, Matsuoka Y, Konogaya Y, Hashzume Y. Multiple system atrophy with remarkable frontal lobe atrophy. Acta Neuropathol 1999; 97: 423-428.

104. Kovacs GG, Voigtlander T, Hainfellner JA, Budka H. Distribution of intraneuronal immunoreactivity for the prion protein in human prion disease. Acta Neuropathol 2002; 104: 320-326.

105. Lantos PL. Cellular pathology of multiple system atrophy: a review. J Neurol Neurosurg Psychiatry 1994; 57: 129-133.

106. Lewis H, Beher D, Cookson N, Oakley A, Piggott M, Morris CM, Jaros E, Perry R, Ince P, Kenny RA, Balard CG, Shearman MS, Kalaria RN. Quantification of Alzheimer pathology in ageing and dementia: age-related accumulation of amyloid beta(42) peptide in vascular dementia. Neuropathol Appl Neurobiol 2006; 32: 103-118

107. Lewy FH. Paralysis agitans. I. Pathologische Anatomie. In: Handbuch der Neurologie. Lewandowsky M (ed.). Springer, Berlin 1912; pp. 920-933.

108. Litvan I, Agid Y, Calne D, Campbell G, Dubois B, Davoisen RC, Goetz CG, Golbe LI, Grafman J, Growden JH, Hallett M, Jankovic J, Quinn NP, Tolisa E, Zee DS, Chase TW, FitzGibbon EJ, Hall Z, Juncos J, Nelson KB, Oliver E, Pramstaller P, Reich SG, Verny M. Clinical research criteria for the diagnosis of progressive supranuclear palsy (Steele-Richardson-Olszewski syndrome): report of the NINDS-SPSP International Workshop. Neurology 1996; 47: 1-9.

109. Litvan I, Grimes DA, Lang AE, Jankovic J, McKee A, Verny M, Jellinger K, Chaudhuri KR, Pearce RKB. Clinical features differentiating patients with postmortem confirmed progressive supranuclear palsy and corticobasal degeneration. J Neurol 1999; 246: 1-5.

110. Lobotesis K, Fenwick JD, Phipps A, Ryman A, Swann A, Ballard C, McKeith IG, O'Brien JT. Occipital hypoperfusion on SPECT in dementia with Lewy bodies but not Alzheimer's disease. Neurology 2001; 56: 643-649.

111. Love S, Saitoh T, Quijada S, Cole GM, Terry RD. Ubiquitin and tau immunoreactivity of neurofibrillary tangles, Pick bodies and Lewy bodies. J Neuropathol Exp Neuro 1988; 47: 393-405.

112. Lowe J, Mayer RJ, Landon M. Ubiquitin in neurodegenerative diseases. Brain Pathol 1993; 3: 55-65. 
113. Mackenzie IRA, Hudson LP. Achromatic neurons in the cortex of progressive supranuclear palsy. Acta Neuropathol 1995; 90: 615-619.

114. Mackenzie IR, Baborie A, Pickering-Brown S, Du Plessis D, Jaros E, Perry RH, Neary D, Snowden JS, Mann DMA. Heterogeneity of ubiquitin pathology in frontotemporal lobar degeneration: classification and relation to clinical phenotype. Acta Neuropathol 2006; 112: 539-549.

115. McKenzie JE, Gentleman SM, Roberts GW, Graham DI, Royston MC. Increased numbers of $\beta$ APP-immunoreactive neurons in the entorhinal cortex after head injury. Neuroreport 1994; 6: 161-164.

116. Mann DMA. The topographic distribution of brain atrophy in Alzheimer's disease. Acta Neuropathol 1991; 83: 81-86.

117. Mann DMA, Brown SMP, Owen F, Baba M, Iwasubo T. Amyloid beta protein $(A \beta)$ deposition in dementia with Lewy bodies: predominance of $A \beta 42 / 43$ and a paucity of $A \beta 40$ compared with sporadic Alzheimer's disease. Neuropathol Appl Neuro 1988; 24: 187-194.

118. Martinez-Martin P. Is AD a homogeneous entity? Yes. J Neural Transm (Vienna) 2013; 120: 1467-1473.

119. Mathuranath PS, Xureb JH, Bak T, Hodges JR. Corticobasal ganglionic degeneration and/or frontotemporal dementia? A report of two overlap cases and review of the literature. J Neurol Neurosurg Psychiatry 2000; 68: 304-312.

120. McKeith IG, Galasko D, Kosaka K, Perry EK, Dickson DW Hansen LA, Salmon DP, Lowe J, Mirra SS, Byrne EJ, Lennox G, Quinn NP, Edwardson JA, Ince PG, Bergeron C, Burns A, Miller BL, Lovestone S, Collerton D, Jansen ENH, Ballard C, de Vos RAl, Wilcock GK, Jellinger KA, Perry RH. Consensus guidelines for the clinical and pathological diagnosis of dementia with Lewy bodies (DLB): report of the consortium on DLB international workshop. Neurology 1996; 47: 1113-1124.

121. Minoshima S, Foster NL, Sima AAF, Frey KA, Abin RL, Kuhl DE. Alzheimer's disease versus dementia with Lewy bodies: cerebral metabolic distinction with autopsy confirmation. Ann Neurol 2001; 50: 358-365.

122. Miller DL, Papayannopoulos IA, Styles J, Bobin SA, Lin YY, Biemann K, Igbal K. Peptide compositions of the cerebrovascular and senile plaque core amyloid deposits of Alzheimer's dis ease. Arch Biochem Biophys 1993; 301: 41-52.

123. Minamu M, Mizutani T, Kawanishi R, Suzuki Y, Mori H. Neu ronal expression of alpha $B$ crystalline in cerebral infarction. Acta Neuropathol 2003; 105: 549-554.

124. Mizuno Y, Hori S, Kakizuka A, Okamoto K. Vacuole-creating protein in neurodegenerative diseases in humans. Neurosci Lett 2005; 343: 77-80.

125. Mirra SS, Heyman A, McKeel D, Sumi SM, Crain BJ, Brownlee LM, Vogel FS, Hughes JP, van Belle G, Berg L. The consortium to establish a registry for Alzheimer's disease (CERAD). Part II. Standardization of the neuropathologic assessment of Alzheimer's disease. Neurology 1991; 41: 479-486.

126. Mori H, Oda M. Ballooned neurons in corticobasal degeneration and progressive supranuclear palsy. Neuropathology 1997; 7: 248-252.

127. Morris HR, Baker M, Yasojima K, Khan NM, Wood NW, Hardy J, Grossman M, Trojanoswki J, Revesz T, Bigio EH, Bergeron C,
Janssen JC, McGeer PL, Rossor MN, Lees AJ, Lantos OL, Hutton M. Analysis of tau haplotypes in Pick's disease. Neurology 2002; 59: 443-445.

128. Morris JC. The nosology of dementia. Neurol Clin 2000; 18: 773.

129. Nakamura S, Kawamoto Y, Nakano S, Akiguchi I, Kimura J. Cyclin-dependent kinase 5 and nitrogen-activated protein kinase in glial cytoplasmic inclusions in multiple system atrophy. J Neuropath Exp Neur 1998; 57: 690-698.

130. Neumann M, Kretzschmar HA. Pathology and biochemistry of frontotemporal dementias. Nervenheilkunde 2004; 23: 73-79.

131. Neumann M, Sampathu DM, Kwong LK, Truax AC, Micsenyi MC, Chou TT, Bruce J, Schuck T, grossman M, Clarke CM, McCluskey LF, Miller BL, Masliah E, Mackenzie IR, Feldmen H, Feiden W, Kretzschmar HA, Trojanowski JQ, Lee VMY. Ubiquinated TDP-43 in frontotemporal lobar degeneration and amylotrophic lateral sclerosis. Science 2006; 314: 130-133.

132. Neumann M, Roeher S, Kretzschmar HA, Rademakers R, Baker M, Mackenzie IRA. Abundant FUS-immunoreactive pathology in Neuronal intermediate filament inclusion disease (NIFID). Acta Neuropathol 2009; 118: 605-616

133. Newell KL, Hyman BT, Growden JH, Hedley-Whyte ET. Application of the National Institute on Aging (NIA)-Reagan Insitute criteria for the neuropathological diagnosis of Alzheimer's disease. J Neuropathol Exp Neurol 1999; 58: 1147-1155.

134. Noda K, Katayama S, Watanabe C, Yamamura Y, Nakamura S. Gallyas and tau positive glial structures in motor neuron disease with dementia. Clin Neuropathol 1999; 18: 218-225.

135. Papp MI, Lantos PL. The distribution of oligodendroglial inclusions in multiple system atrophy and its relevance to clinical symptomology. Brain 1994; 117: 235-243.

136. Pearson RCA, Esiri MM, Hiorns RW, Wilcock GK, Powell TPS. Anatomical correlates of the distribution of the pathological changes in the neocortex in Alzheimer's disease. Proc Natl Acad Sci U S A 1985; 82: 4531-4534.

137. Perl DP, Olanow CW, Calne D. Alzheimer's disease and Parkinson's disease: distinct entities or extremes of a spectrum of neurodegeneration? Ann Neurol 1998; 44: S19-S31.

138. Piao YS, Hayashi S, Hasegawa M, Wakabayashi K, Yamada M, Yoshimoto M, Ishikawa A, Iwatsubo T, Takahashi H. Co-localisation of $\alpha$-synuclein and phosphorylated tau in neuronal and $\mathrm{GCl}$ in a patient with multiple system atrophy of long duration. Acta Neuropathol 2001; 101: 285-293.

139. Pick A. Uber einen weiteren Symptomenkomplex im Rahman der Dementia senilis, bedingt durch umschriebene starkere Hirnatrophie (gemischte Apraxie). Monat Psych Neurol 1906; 19: 97-108.

140. Pielou EC. An Introduction to Mathematical Ecology. J. Wiley, New York, London, Sydney, Toronto 1969.

141. Pierucci A, de Oliveira AL. Increased sensory neuron apoptotic death two weeks after peripheral axontomy in C57BL/6J mice compared to A/J mice. Neurosci Lett 2006; 396: 127-131.

142. Pike CJ, Cotman CW. Calretinin-immunoreactive neurons are resistant to $\beta$-amyloid toxicity in vitro. Brain Res 1995; 671: 293-298.

143. Reed LA, Schmidt ML, Wszolek ZK, Balin BJ, Soontornniyomkij V, Lee VMY, Trojanowski JQ, Schelper RL. The neuropathology of a chromosome 17-linked autosomal dominant parkino- 
sism and dementia ("pallidoponto-nigral degeneration"). J Neuropath Exp Neur 1998; 57: 588-601

144. Rezaie P, Cairns NJ, Chadwick A, Lantos PL. Lewy bodies are located preferentially in limbic areas in diffuse Lewy body disease. Neurosci Lett 1996; 212: 111-114.

145. Ritchie K, Touchon J. Heterogeneity in senile dementia of the Alzheimer type: individual differences, progressive deterioration or clinical subtypes? J Clin Epidemiol 1992; 45: 1391-1398.

146. Roher AE, Lowenson JD, Clarke S, Wolkow W, Wang R, Cotter RJ, Reardon IM, Zurcherneely HA, Heinrikson RL, Ball MJ, Greenberg BD. Structural alterations in the peptide backbone of $\beta$-amyloid core protein may account for its deposition and stability in Alzheimer's disease. J Biol Chem 1993; 268: 30723073.

147. Rosenberg CK, Pericak-Vance MA, Saunders AM, Gilbert JR, Gaskell PC, Hulette CM. Lewy body and Alzheimer pathology in a family with the amyloid-beta precursor protein APP717 gene mutation. Acta Neuropathol 2000; 100: 145-152.

148. Sabbagh MN, Sandhu SS, Farlow MR, Veddeis L, Shell HA, Caviness JN, Connor DJ, Sue L, Adler CH, Beach TG. Correlation of clinical features with argyrophilic grains at autopsy. Alz Dis Assoc Dis 2009; 23: 229-233.

149. Saito Y, Kawashima A, Ruberu NN, Fujiwara H, Koyama S, Sawaki M, Arai T, Nagura H, Yamanouchi H, Hasegawa M, Iwatsubo T, Murayama S. Accumulation of phosphorylated $\alpha$-synuclein in aging human brain. J Neuropath Exp Neurol 2003; 62: 644-654.

150. Sampathu DM, Neumann M, Kwong LK, Chou TT, Micsenyi M, Truax A, Bruce J, Grossman M, Trojanowski JQ, Lee VM. Pathological heterogeneity of frontotemporal lobar degeneration with ubiquitin-positive inclusions delineated by ubiquitin immonohistochemistry and novel monoclonal antibodies. Am J Pathol 2006; 189: 1343-1352.

151. Saper CB, Wainer BH, German DC. Axonal and transneural transport in the transmission of neurological disease: potential role in system degenerations including Alzheimer's disease. Neuroscience 1987; 23: 389-398.

152. Schulz-Schaeffer WJ, Giese A, Windl O, Kretschmar HA. Polymorphism at codon 129 of the prion protein gene determines cerebellar pathology in Creutzfeldt-Jakob disease. Clin Neuropathol 1996; 15: 353-357.

153. Shinotoh H, Namba H, Yamaguchi M, Fukushi K, Nagatsuka S, Iyo M, Asahina M, Hattori T, Tanada S, Irie T. Positron emission tomographic measurement of acetylcholinesterase activity reveals differential loss of ascending cholinergic systems in Parkinson's disease and progressive supranuclear palsy. Ann Neurol 1999; 46: 62-69.

154. Spillantini MG, Crowther RA, Jakes R, Cairns NJ, Lantos PL, Goedert M. Filamentous alpha-synuclein inclusions link multiple system atrophy with Parkinson's disease and dementia with Lewy bodies. Neurosci Lett 1998; 251: 205-208.

155. Steiner JA, Angot E, Brunden P. A deadly spread: cellular mechanisms of $\alpha$-synuclein transfer. Cell Death Differ 2011; 18 1425-1433.

156. Steinling M, Defebvire L, Duhamel A, Lecouffe P, Lavenu I, Pasquier F, Charpentier P. Is there a typical pattern of brain SPECT imaging in Alzheimer's disease? Dement Geriatr Cogn 2001; 12: 371-378.

157. Struble RG, Powers RE, Casanova MF, Kitt CA, Brown EC, Price DL. Neuropeptidergic systems in plaques in Alzheimer's disease. J Neuropath Exp Neurol 1987; 46: 567-584.

158. Suzuki K, Parker CC, Pentchev PG. Niemann-Pick disease type C: neuropathology revisited. Dev Brain Dyst 1997; 10: 306-320.

159. Tabaton M, Perry G, Gambelli L, Manello V, Gambetti P. Influence of neuronal location on antigenic properties of neurofibrillary tangles. Ann Neurol 1988; 23: 604-610.

160. Talbot P. Fronto-temporal dementia. Alzheimer's Review 1997; 6: 1-5.

161. Talbot PR, Goulding PJ, Lloyd JJ, Snowden JS, Neary D, Testa HJ. Interrelation between classic motor neuron disease and frontotemporal dementia: neuropsychological and single-photon emission computed tomography study. J Neurol Neurosur Psychiatry 1995; 58: 541-547.

162. Tierney M, Fisher R, Lewis A, Zorzitto M, Snow W, Reid D, Nieuwstraten P. The NINCDS-ADRDA work group criteria for the clinical diagnosis of probable Alzheimer's disease. Neurology 1988; 38: 359-364.

163. Tolnay M, Monsch AU, Staehelin HB, Probst A. Argyrophilic grain disease: a disorder distinct from Alzheimer's disease. Pathologe 1999; 20: 159-168.

164. Trojanowski JQ, Dickson D. Update on the neuropathological diagnosis of frontotemporal dementias. J Neuropath Exp Neurol 2001; 60: 1123-1126.

165. Troncoso JC, Sukhov RR, Kawas CH, Koliatsos VE. In situ labelling of dying cortical neurons in normal aging and in Alzheimer's disease: correlations with senile plaques and disease progression. J Neuropath Exp Neurol 1996; 55: 1134-1142.

166. Verga L, Frangione B, Tagliavini F, Giaccone G, Migheli A, Bugiani O. Alzheimer's and Down's patients: cerebral preamyloid deposits differ ultrastructurally and histochemically from the amyloid of senile plaques. Neurosci Lett 1989; 105: 294299.

167. Wakabayashi K, Takahashi H. Pathological heterogeneity in progressive supranuclear palsy and corticobasal degeneration. Neuropathology 2004; 24: 79-86.

168. Wakabayashi K, Ikeuchi T, Ishikawa A, Takahashi H. Multiple system atrophy with severe involvement of the motor cortical areas and cerebral white matter. J Neurol Sci 1998; 156: 114117.

169. Wallin A, Blennow K. Clinical subgroups of Alzheimer's syndrome. Acta Neurol Scand 1996; 93: 51-57.

170. Wenning GK, Quinn NP. Multiple system atrophy. Baillieres Clin Neur 1997; 6: 187-204.

171. Wenning GK, Tison F, Ben-Shlomo Y, Daniel SE, Quinn NP. Multiple system atrophy: a review of 203 pathologically proven cases. Movement Disord 1997; 12: 133-147.

172. Whitwell JL, Jack CR, Senjern ML, Josephs KA. Patterns of atrophy in pathologically confirmed FTLD with or without motor neuron degeneration. Neurology 2006; 66: 102-104.

173. Williams DR, de Silva R, Paviour DC, Pittman A, Watt HC, Kilford L, Holton JL, Revesz T, Lees AJ. Characteristics of two distinct clinical phenotypes in pathologically proven progressive 
supranuclear palsy: Richardson's syndrome and PSP-parkinsonism. Brain 2005; 128: 1247-1258.

174. Yaar M, Zhai S, Pilch PF, Doyle SM, Eisenhauer PB, Fine RE, Gilchrest BA. Binding of beta-amyloid to the p75 neurotrophic receptor induces apoptosis: a possible mechanism for Alzheimer's disease. J Clin Invest 1997; 100: 2333-2340.

175. Yamada T, McGeer PL, McGeer EG. Appearance of paired nucleated tau-positive glia in patients with progressive supranuclear palsy brain tissue. Neurosci Lett 1992; 135: 99-102.

176. Yamaguchi H, Ishigura K, Sugihara S, Nakazato Y, Kawarabayashi T, Sun XY, Hirai S. Presence of apolipoprotein $\varepsilon$ on extracellular neurofibrillary tangles and on meningeal blood vessels precedes the Alzheimer $\beta$-amyloid deposition. Acta Neuropathol 1994; 88: 413-419.

177. Yokota O, Tsuchiya K, Terada S, Ishizu H, Uchikado H, Ikeda M, Oyenagi K, Nakamo I, Murayama S, Kuroda S, Akiyama H. Basophilic inclusion body disease and neuronal intermediate filament inclusion disease: a comparative clinicopathological study. Acta Neuropathol 2008; 115: 561-575.

178. Zhukareva V, Shah K, Uryu K, Braak H, del Tredici K, Sundarraj S, Clark C, Trojanowski JQ, Lee VMY. Biochemical analysis of tau proteins in argyrophilic grain disease, Alzheimer's disease and Pick's disease: a comparative study. Am J Pathol 2002; 161: 1135-1141. 